Volume 12, Nomor 2, November 2020, pp 337-349 Copyright (C) 2017

Jurnal Akuntansi, Program Studi Akuntansi, Fakultas Ekonomi, Universitas Kristen Maranatha. ISSN 2085-8698 | e-ISSN 2598-4977. http://journal.maranatha.edu

\title{
Dampak Kualitas Laporan Keuangan Perusahaan Badan Usaha Milik Negara Terhadap Efisiensi Investasi
}

\author{
Novita Sherla Hariyanto ${ }^{1}$ \\ Fakultas Ekonomi dan Bisnis, Universitas Ma Chung \\ Villa Puncak Tidar N-01, Malang 65151, Indonesia \\ sherlahariyanto97@gmail.com \\ Tarsisius Renald Suganda ${ }^{2}$ \\ Fakultas Ekonomi dan Bisnis, Universitas Ma Chung \\ Villa Puncak Tidar N-01, Malang 65151, Indonesia \\ renald.suganda@machung.ac.id \\ Putu Indrajaya Lembut ${ }^{3}$ \\ Fakultas Ekonomi dan Bisnis, Universitas Ma Chung \\ Villa Puncak Tidar N-01, Malang 65151, Indonesia \\ putu.indrajaya@machung.ac.id
}

\begin{abstract}
This study aims to investigate the effects of financial statements' quality towards over/under investment, the internal controls' implementation towards over/under investment, and moreover the internal control as a moderating variable to strengthen the financial statements' quality to over/under investment on state-owned listed companies in Indonesia Stock Exchange and state-owned non-listed companies as well. The data analysis techniques namely logistic regression analysis is used to measure the research problems. There are 96 listed and non-listed state-owned companies (not including financial services and insurance) used as research sample during period from 2015 to 2018. The findings of this study reject first and third hypotheses stating that the financial statements' quality does not affect over/under investment and moreover, internal control as a moderating variable could not strengthen the effect of financial statements' quality towards over/under investment. However, on the other hand, the second hypothesis in this study is accepted proofing that the implementation of internal control has positive effect on over/under investment.
\end{abstract}

Keywords: Quality of Financial Statements, The Internal Control, Investment Efficiency, State Owned Enterprises 


\begin{abstract}
Abstrak
Tujuan dari penelitian ini adalah untuk menginvestigasi pengaruh kualitas laporan keuangan terhadap over/under investment, pelaksanaan pengendalian internal terhadap over/under investment, dan pelaksanaan pengendalian internal sebagai variabel pemoderasian dalam upaya meningkatkan kualitas laporan keuangan terhadap over/under investment pada perusahaan Badan Usaha Milik Negara yang terdaftar di Bursa Efek Indonesia maupun perusahaan BUMN yang tidak terdaftar di bursa. Teknik analisis data yaitu analisis regresi logistik digunakan untuk menjawab pertanyaan penelitian. Sejumlah 96 perusahaan Badan Usaha Milik Negara secara total yang berasal dari bursa dan di luar bursa (sektor jasa keuangan dan asuransi dikecualikan) digunakan sebagai sampel pada periode 2015 sampai dengan 2018. Hasil dari penelitian ini menolak hipotesis pertama dan ketiga yaitu kualitas laporan keuangan tidak mampu mempengaruhi terhadap over/under investment dan pengendalian internal sebagai variabel pemoderasian tidak mampu memperkuat pengaruh kualitas laporan keuangan terhadap over/under investment. Namun sebaliknya, hipotesis kedua pada penelitian ini berhasil dibuktikan yaitu bahwa pengendalian internal berpengaruh positif terhadap over/under investment.
\end{abstract}

\title{
Kata Kunci: Kualitas Laporan Keuangan, Pengendalian Internal, Efisiensi Investasi, Badan Usaha Milik Negara.
}

\section{Pendahuluan}

Secara rasional, investor diharapkan mengambil keputusan untuk berinvestasi pada perusahaan yang memiliki citra atau prospek yang baik berdasarkan argumen bahwa investor memiliki ekspektasi untuk memperoleh imbal hasil atau tingkat kembalian investasi. Dalam hal ini, baik individu maupun perusahaan sebagai investor, sama-sama dituntut untuk lebih efisien dalam berinvestasi. Perencanaan dan pengalokasian serta pemanfaatan sumber daya yang tepat pada akhirnya dipercaya mampu menciptakan investasi yang optimal dan terhindar dari keadaan over investment maupun under investment.

Over investment merupakan suatu kondisi yang menunjukkan bahwa jumlah investasi oleh perusahaan lebih tinggi dibandingkan dengan yang diekspektasikan. Menurut Sari \& Suaryana (2014), isu over investment rata-rata dialami oleh beberapa perusahaan yang dalam kondisi mature yaitu perusahaan dengan tingkat pertumbuhan yang lambat (slow growth), dan juga memiliki aset dan arus kas bebas 338 dalam jumlah yang besar. Berkebalikan dengan kondisi tersebut, under investment merujuk pada sejumlah investasi yang dilakukan perusahaan jauh lebih rendah dibandingkan dengan yang diharapkan. Under investment terjadi jika perusahaan dihadapkan pada kesempatan investasi yang melibatkan utang dalam jumlah yang besar, namun tidak membutuhkan jaminan pembayaran yang cukup (Sari \& Suaryana, 2014)

Teori keagenan menyatakan baik masalah over investment maupun under investment dapat dijelaskan dengan adanya informasi yang tidak simetris di antara para pemegang kepentingan (Gomariz \& Ballesta, 2014). Problematika ini timbul akibat adanya asimetri informasi antara pihak prinsipal dan agen. Hal ini mengakibatkan manager sebagai agen di perusahaan terkadang tidak memaksimalkan value bagi para pemegang saham dengan melakukan tindakan yang dapat menguntungkan pribadinya. Akibatnya, di dalam keputusan investasi, asimetri informasi dapat berujung pada masalah over investment maupun under investment, 
sehinga perusahaan terkendala dalam menghasilkan investasi yang efisien.

Banyak literatur memberikan informasi bahwa perusahaan dapat mengurangi asimetri informasinya dengan memperhatikan kualitas laporan keuangannya. Laporan keuangan yang berkualitas adalah cerminan kinerja bagi perusahaan pada periode tertentu yang diharapkan dapat memberi manfaat pada para stakeholders. Selain itu, laporan keuangan yang memiliki kualitas baik akan bedampak pada pengawasan yang lebih baik sehingga meminimalisir terjadinya over investment maupun under investment. Chung, et al., (2013) berpendapat bahwa kualitas akuntansi melalui laporan keuangan berpengaruh besar terhadap investasi yang efisien, terlebih hal tersebut akan berhubungan dengan risiko yang ada dalam setiap pengambilan keputusan perusahaan. Laporan keuangan dengan kualitas yang lebih tinggi akan memungkinkan pengawasan yang lebih baik sehingga asimetri informasi dapat berkurang. Selain itu, mengurangi adverse selection dan moral hazard adalah suatu upaya bagi manajer untuk mampu mengidentifikasi kesempatan berinvestasi yang potensial sehingga dapat meningkatkan investasi yang efisien (Gomariz \& Ballesta, 2014).

Salah satu faktor penyebab kualitas laporan keuangan yang buruk adalah sistem pengendalian internal yang tidak berjalan dengan baik di dalam perusahaan. Pengendalian internal yang buruk yang akan mengakibatkan rendahnya kualitas laporan biasanya ditandai dengan banyaknya kesalahan prosedural dan estimasi yang dilakukan oleh manajemen (Jaehong, et al., 2016). Teori keagenan menyarankan perusahaan untuk menyajikan mekanisme monitoring secara efektif dalam hal mengeliminasi perilaku oportunis seorang manajer. Salah satu bentuk mekanisme dan upaya monitoring untuk mengeliminasi potensi tindakan kecurangan yang mungkin terjadi di dalam perusahaan adalah dengan jalan mengupayakan sistem pengendalian internal yang ada dalam perusahaan dan dilaksanakan sesuai prosedur.

Hasil studi riset yang dilakukan selama ini memberi gambaran bahwa kualitas laporan keuangan meningkat sejalan dengan peningkatan pengendalian internal di dalam perusahaan (Lambert, et al., 2007; Ashbaugh-Skaife, et al., 2008) dan kualitas laporan yang tinggi mampu mendongkrak efisiensi investasi (Biddle, et al., 2009). Temuan tersebut bermakna bahwa pengendalian internal yang tepat mampu mengeliminasi adanya kesenjangan informasi sehingga pada akhirnya mampu meningkatkan efisiensi investasi. Chalmers, et al., (2018) melakukan kajian beberapa studi pengendalian internal dan menemukan bahwa pengendalian internal memiliki dampak yang signifikan terhadap pengambilan keputusan para pengguna informasi. Pengendalian internal yang lemah menunjukkan permasalahan terkait informasi di dalam perusahaan sehingga dapat diduga bahwa perusahaan akan menunjukkan perilaku investasi yang tidak efisien. Perusahaan yang menerapkan pengendalian internal yang baik memiliki dampak pada investasi optimal, yang pada akhirnya meminimalisir terjadinya over investment dan under investment.

Salah satu isu yang perlu diinvestigasi lebih lanjut adalah isu bahwa perusahaan BUMN yaitu PT Garuda Indonesia (Persero) Tbk melakukan perekayasaan keuangan di tahun 2019. Kasus ini diawali dengan adanya dugaan kuat oleh BPK bahwa telah terjadi financial engineering dalam perusahaan. BPK menemukan adanya pengakuan piutang perusahaan pada laporan keuangan yang menunjukkan bahwa proses audit laporan keuangan Garuda Indonesia tidak sepenuhnya mengikuti standar akuntansi yang berlaku. Lebih lanjut, pihak manajemen Garuda Indonesia melakukan perubahan atas laporan keuangan Tahun Anggaran (Buku) 2018 dan menyatakan 
(financial report restatement) bahwa korporasi mengalami kerugian $\mathrm{Rp} 2.4$ triliun, yang sebelumnya laporan keuangan mencatatkan laba Rp 11.5 Miliar. Artinya, selisihnya merupakan rekayasa laporan atau penipuan yang telah dilakukan oleh Direksi Garuda Indonesia (diakses dari linkpublik.com). Hal ini tentu menjadi kerugian baik bagi emiten maupun investor. Dibuktikan pula dengan pergerakan saham GIAA (kode saham Garuda Indonesia) kembali menunjukkan tren prenurunan. (http://investasi.kontan.co.id/news/laporankeuangan-bermasalah-ini-rekomendasianalis-untuk-investor-garuda-indonesia).

Dari peristiwa tersebut, dapat diduga bahwa selain laporan keuangan PT Garuda Indonesia patut dipertanyakan kualitasnya, juga kurang baiknya pelaksanaan pengendalian internal di dalam perusahaan. Selain itu, perusahaan Garuda Indonesia belum menerapkan dengan baik peraturan Otoritas Jasa Keuangan (OJK) Nomor 75/POJK.04/2017 tentang Tanggung Jawab Direksi atas Laporan Keuangan. Peraturan tersebut mengharuskan direksi perusahaan membuat pernyataan tertulis diatas materai bahwa tanggung jawab atas penyusunan dan penyajian laporan keuangan sesuai standar akuntansi yang berlaku.

Penelitian ini merupakan pengembangan dari penelitian terdahulu yang dilakukan oleh Pradana, et al., (2017). Perbedaan penelitian ini dengan penelitian Pradana, et al., (2017) adalah bahwa penelitian ini menggunakan periode pengamatan terbaru dan menggunakan dasar peraturan Otoritas Jasa Keuangan (OJK) Nomor 75/POJK.04/2017.

\section{Kerangka Teoritis dan Hipotesis} Teori Agensi

Jensen \& Meckling (1976) mendefinisikan hubungan agensi sebagai kontrak antara pihak yang memberi wewenang (principals) dan pihak yang menerima wewenang (agent) untuk menjalankan aktivitas perusahaannya. Dalam hal ini, manajer dipandang sebagai agen dan para pemegang saham sebagai prinsipal. Teori keagenan merupakan teori yang melandasi penelitian ini yang menjelaskan hubungan antara prinsipal dan agen untuk melakukan kegiatan tertentu guna kepentingan pemilik modal. Laporan keuangan yang berkualitas akan memungkinkan pengawasan yang lebih baik sehingga manajer lebih bertanggung jawab (Gomariz \& Ballesta, 2014). Selain itu, laporan keuangan yang berkualitas diperkirakan sangat membantu manajer dalam menghasilkan keputusan-keputusan investasi yang sesuai.

\section{Kualitas Laporan Keuangan dan Efisiensi Investasi}

Dalam teori neo-klasik, dikemukakan bahwa pengaruh investasi terhadap nilai perusahaan bisa terjadi apabila nilai biaya marjinal lebih rendah daripada nilai kebermanfaatan marjinal investasinya (Biddle, et al., 2009). Keuntungan marjinal akan didapatkan jika perusahaan berinvestasi pada proyek-proyek yang memiliki net present value positif sehingga dapat meningkatkan nilai perusahaan yang pada akhirnya memberikan return bagi investor.

Adanya kesenjangan informasi dapat menyebabkan investasi berjalan tidak optimal (Jensen \& Meckling, 1976). Ketika kualitas akuntansi tinggi, seharusnya asimetri informasi diharapkan rendah yang pada akhirnya mengurangi sensitivitas investasi terhadap arus kas (Beatty, et al., 2010).

Informasi pada laporan keuangan merupakan sumber pedoman bagi para pemegang saham untuk mengawasi kinerja pihak manajemen yang kerapkali menjadi sumber informasi spesifik yang penting (Lambert, 2007). Apabila laporan keuangan tersebut berkualitas baik, maka akan dipastikan mampu meningkatkan kemampuan para stockholders untuk memantau aktivitas investasi manajerial, yang dapat dikaitkan dengan efisiensi investasi dengan mengurangi moral hazard. 
Biddle, et al., (2009) menyatakan bahwa kualitas laporan keuangan memiliki hubungan negatif dengan kondisi over investment dan under investment. Adanya kualitas laporan keuangan yang baik akan dapat meningkatkan fungsi monitoring dari pemegang saham sehingga dapat mengurangi kemungkinan terjadinya kondisi over atau under investment.

Berdasarkan kajian teoretis dan hasil riset empiris tersebut, maka hipotesis yang dapat dirumuskan adalah sebagai berikut:

H1a: kualitas laporan keuangan berpengaruh negatif terhadap over investment.

H1b: kualitas laporan keuangan berpengaruh negatif terhadap under investment.

\section{Pengendalian Internal dan Efisiensi Investasi}

Berdasarkan Peraturan Pemerintah No. 60 Tahun 2008 pengertian pengendalian internal adalah proses yang melibatkan pimpinan dan karyawan untuk memberikan keyakinan memadai dalam mencapai tujuan organisasi melalui kegiatan yang efisien dan efektif, laporan keuangan yang andal, pengamanan aset negara dan patuh terhadap Undang-Undang yang berlaku. Pengendalian internal diduga mampu mempengaruhi efisiensi investasi karena pengendalian internal dapat menurunkan asimetri informasi antara agen dan prinsipal. Perusahaan yang menerapkan pengendalian internal yang baik maka investasi yang dilakukan perusahaan menjadi optimal, kemungkinan terjadinya over investment dan under investment mengalami penurunan. Semua organisasi tentu membutuhkan informasi sebagai dasar pengambilan keputusan untuk mencegah dan meminimalisir terjadinya kesalahan akibat kecurangan dan kesalahan untuk mencapai investasi yang efisien (Susanto, 2016).

Pengendalian internal menjadi sangat penting untuk mengurangi kemungkinan terjadinya efisiensi investasi.
Chalmers, et al., (2018) telah melakukan kajian pada beberapa penelitian pengendalian internal dan menemukan bahwa kualitas pengendalian internal mampu memberikan dampak signifikan terhadap pengambilan keputusan para pengguna informasi tersebut. Adanya kelemahan pada pengendalian internal perusahaan menunjukkan adanya masalah informasi dalam sistem laporan keuangan perusahaan, sehingga diperkirakan terdapat perilaku investasi yang tidak efisien.

Berdasarkan beberapa kajian teori dan hasil penelitian tersebut maka hipotesis penelitian ini yaitu terdapat pengaruh pengendalian internal internal terhadap efisiensi investasi melalui over atau under investment sebagai berikut:

H2a: pengendalian internal berpengaruh positif terhadap over investment.

H2b: pengendalian internal berpengaruh positif terhadap under investment.

$\begin{array}{lcc}\begin{array}{l}\text { Kualitas } \\ \text { Pengendalian } \\ \text { Investasi }\end{array} & \begin{array}{c}\text { Laporan } \\ \text { Internal }\end{array} & \begin{array}{r}\text { Keuangan, } \\ \text { dan }\end{array} \\ & & \end{array}$

Peraturan Otoritas Jasa Keuangan (OJK) Nomor 75/POJK.04/2017 tentang Tanggung Jawab Direksi atas Laporan Keuangan mengharuskan direksi perusahaan untuk membuat pernyataan tertulis di atas materai bahwa tanggung jawab atas penyusunan dan penyajian laporan keuangan sesuai prinsip akuntansi yang berlaku umum/ standar akuntansi keuangan yang berlaku di Indonesia dan bertanggungjawab atas sistem pengendalian internal dalam perusahaan. Setelah regulasi tersebut terbit, pada kenyataannya sistem pengawasan terhadap manajer perusahaan belum berjalan optimal.

Berdasarkan Keputusan Menteri Negara Badan Usaha Milik Negara Nomor: Per-01/MBU/2011 tentang Penerapan Tata Kelola Perusahaan yang Baik (Good Corporate Governance) pada BUMN pada Pasal 2 menyebutkan kewajiban BUMN menerapkan GCG, direksi menyusun GCG manual yang diantaranya memuat sistem 
pengendalian intern. Oleh pemerintah indikator pelaksanaan sistem pengendalian intern ini akan diperiksa dan diungkapkan melalui BPK melalui Ikhtisar Hasil Pemeriksaan Semester (IHPS) setiap tahun

Mulyani \& Suryawati (2011) menunjukkan bahwa pengendalian internal yang baik dapat meminimalisasi salah saji laporan keuangan di Indonesia. Jadi, laporan keuangan yang disajikan mempunyai informasi yang lebih akurat dan tepat. Dengan demikian keberadaan pengendalian internal berpengaruh positif terhadap kualitas laporan keuangan. Perusahaan dengan pengendalian internal yang lemah akan cenderung memiliki ketidakakuratan hasil dalam laporan keuangannya sehingga kualitas akuntansinya bisa dikatakan lebih rendah. Dalam hal ini, laporan keuangan tidak dapat memainkan peran mengurangi adverse selection dan moral hazard yang timbul dari asimetri informasi antara perusahaan dan investor (Jaehong, et al., 2016).

Pengendalian internal yang efektif diharapkan dapat berkontribusi positif bagi para pihak internal dan eksternal perusahaan untuk mengurangi salah saji informasi keuangan sehingga menyebabkan laporan keuangan menjadi lebih reliabel. Oleh sebab itu, dengan adanya pengendalian internal yang baik, maka akan berdampak pada tingginya kualitas laporan keuangan perusahaan yang diungkapkan oleh manajemen perusahaan yang diduga dapat mengurangi asimetri informasi dan menekan adanya investasi dengan tidak efisien atau inefisien.

Berdasarkan hal tersebut, maka hipotesis yang diangkat dalam penelitian ini yaitu sebagai berikut:

H3a: pengaruh kualitas laporan keuangan terhadap over investment lebih kuat pada BUMN yang melaksanakan pengendalian internalnya.

H3b: pengaruh kualitas laporan keuangan terhadap under investment lebih kuat pada BUMN yang melaksanakan pengendalian internalnya.

\section{Metode Penelitian}

\section{Populasi dan Sampel}

Menurut Sekaran \& Bougie (2017), populasi adalah kelompok orang, kejadian atau hal-hal menarik dimana peneliti ingin membuat opini (berdasarkan statistik sampel). Populasi yang digunakan dalam penelitian ini adalah perusahaan BUMN di Indonesia baik yang listed dan non-listed (kecuali jasa keuangan dan asuransi) berbentuk peseroan terbatas (PT) dalam periode waktu tahun 2015-2018 sesuai hasil publikasi laporan keuangan yang telah diaudit dari Kementrian BUMN RI.

Sampel dipilih dengan berdasarkan pda kriteria: Pertama, BUMN terdaftar pada Kementerian BUMN RI dan BEI pada tahun 2015-2018; Kedua, data perusahaan yang diperlukan tersedia dengan lengkap untuk proses analisis data; Ketiga, data yang digunakan dalam penelitian ini berasal dari ikhtisar laporan keuangan perusahaan BUMN yang terpublikasi di situs Kementerian BUMN; Keempat, laporan keuangan tahunan masing - masing BUMN dan Ikhtisar Hasil Pemerikasaan Semester (IHPS) dikeluarkan oleh BPK RI.

\section{Variabel dan Definisi Operasional \\ Efisiensi Investasi}

Model untuk mengukur efisiensi investasi sebagai berikut.

Investment $\mathrm{i}, \mathrm{t}=\beta 0+\beta 1$ Sales Growthi, $\mathrm{t}-1+$ $\varepsilon \mathrm{i}, \mathrm{t}$

Investment $_{\mathrm{i}, \mathrm{t}}=$ Total investasi perusahaan $i$ pada tahun $t$. Diukur dengan kenaikan bersih aset tetap berwujud dan aset tidak berwujud dibagi dengan lagged total aset.

Sales Growth $\mathrm{i,t}=$ tingkat perubahan penjualan perusahaan dari tahun lalu hingga tahun ini.

Perhitungan model investasi (1) di atas akan menghasilkan nilai residual yang akan digunakan sebagai proksi dari efisiensi investasi perusahaan. Kemudian, nilai residual akan dibagi menjadi beberapa 
kuartil, yang mana kuartil paling bawah menunjukkan perusahaan yang masuk ke dalam kategori under investment. Perusahaan pada kuartil paling atas masuk ke dalam kategori perusahaan over investment. Sedangkan, kuartil tengah akan dijadikan sebagai acuan atas penentuan kategori over atau under investment.

\section{Kualitas Laporan Keuangan}

Model pengukuran kualitas laporan keuangan mengikuti model yang dikembangkan oleh Kothari, et al., (2005) dan Chen, et al., (2011). Model ini didasarkan pada pemikiran bahwa akrual membutuhkan asumsi dan estimasi arus kas masa depan. Peran akrual adalah menyesuaikan pengakuan arus kas dari waktu ke waktu, sehingga laba yang disesuaikan akan lebih baik untuk mengukur kinerja perusahaan. Model untuk mengukur kualitas akrual ada sebagai berikut.

$$
\begin{aligned}
\text { TAi,t } t= & a_{0}+a_{1}\left[1 / \operatorname{ASSETS}_{i, t-1}\right]+ \\
& a_{2} \Delta S A L E S i, \mathrm{t}+a_{3} P P E_{i, t}+ \\
& \left.a_{4} R O A_{i, t(\text { or } i, t-1}\right)+\varepsilon_{i, t}
\end{aligned}
$$

Keterangan:

TAi, $\quad=$ Laba Bersih - Arus Kas

dari Aktivitas Operasi

$\triangle S A L E S i, t \quad=$ Penjualant -

Penjualant-1

ROAi,t =Laba Bersih/Total Aset

$P P E i, t \quad=$ Penerimaan Aktiva

Tetap - Penyusutan Aktiva Tetap

Berdasarkan persamaan di atas, akan didapat residual value yang dipakai dalam mengukur seberapa berkualitasnya laporan keuangan tersebut. Residual value dapat dicari dengan membagi ASSETSi,t-1 disetiap variabel, dengan rumus sebagai berikut.

\section{Residual Value}

$$
\begin{aligned}
& =\frac{T A i, t}{\text { ASSETSit }-1}-\frac{\Delta S A L E S i,}{\text { ASSETSit }-1}- \\
& \frac{\text { PPE } i, t}{\text { ASSETSit }-1}-\frac{\text { ROAi }, t}{\text { ASSETS }, t-1}
\end{aligned}
$$

\section{Pengendalian Internal}

Variabel Pengendalian Internal (Internal Control/IC) menggunakan proksi hasil pemeriksaan IHPS oleh BPK dengan menggunakan rasio, dimana hasil pemeriksaaan IHPS oleh BPK memiliki 4 kriteria dengan jumlah persentase $100 \%$. Setiap kriteria memiliki nilai persentase $25 \%$.

\section{Variabel Kontrol}

Variabel kontrol yang digunakan dalam penelitian ini berdasarkan asumsi determinan pengendalian internal dan tingkat investasi yang terdapat pada penelitian Cheng et al. (2013), yaitu:

Pertama, determinan pengendalian internal adalah Size $=\log$ total aset; Age $=$ $\log$ umur perusahaan. Kemudian kedua, determinan tingkat investasi adalah Loss = rugi yaitu menggunakan variabel dummy dengan nilai $1=$ laba negatif dan nilai $0=$ lainnya.

\section{Hasil Penelitian dan Pembahasan}

\section{Statistik Deskriptif}

Gambaran mengenai nilai rata-rata (mean), minimum, maksimum, dan standar deviasi dari keseluruhan perusahaan berdasarkan masing-masing variabel dapat dilihat pada tabel statistik deskriptif dibawah ini :

Tabel 1

Statistik Deskriptif

\begin{tabular}{lrrrrr}
\hline Variabel & N & Minimum & Maksimum & Mean & $\begin{array}{c}\text { Deviasi } \\
\text { Standar }\end{array}$ \\
\hline TAX & 384 & 0,01 & 20,09 & 2.4627 & 3,71085 \\
IHPS & 384 & 0,25 & 1 & 0,5228 & 0.22845 \\
TAXIHPS & 384 & 0,01 & 86,37 & 2,3028 & 6,33049 \\
LnTa & 384 & 4,29870 & 9,13959 & 6,5284237 & 0,96427007 \\
Age & 384 & 3 & 210 & 49,55 & 31,963 \\
Loss & 384 & 0 & 1 & 0,15 & 0,356 \\
\hline
\end{tabular}

Sumber: Data Olahan, 2020

Berdasarkan statistik deskriptif diperoleh 384 data, dapat dijelaskan bahwa nilai mean sebesar 2.4627 menunjukkan nilai rata-rata dari kualitas laporan keuangan dengan 
deviasi standar sebesar 3,71085. Pada pengendalian internal didapat mean sebesar 0,5228 menunjukkan rata-rata dari pengendalian internal dengan deviasi standar sebesar 0.22845. Kualitas laporan keuangan dimoderasi pengendalian internal memiliki nilai mean sebesar 2,3028 menunjukkan rata-rata dari kualitas laporan keuangan dimoderasi pengendalian internal dengan deviasi standar sebesar 6,33049.

\section{Hasil Uji Multikolinearitas}

Asumsi multikolinearitas menyatakan bahwa variabel independen harus terbebas dari gejala multikolinearitas. Suatu model regresi dinyatakan bebas multikolinearitas jika tidak terjadi korelasi yang kuat antara variabel independen yang mana pengujiannya dapat dilakukan dengan melihat nilai tolerance dan Variance Inflation Factor (VIF). Jika nilai tolerance $>0.10$ dan VIF < 10, maka dapat diartikan bahwa tidak terjadi multikolinearitas (Ghozali, 2016).

\section{Tabel 2}

Hasil Uji Multikolinearitas

\begin{tabular}{|c|c|c|}
\hline Variabel & VIF & Tolerance \\
\hline TA & 1.648 & 0.607 \\
\hline IHPS & 1.008 & 0.992 \\
\hline TAXIHPS & 1.658 & 0.603 \\
\hline
\end{tabular}

Sumber: Data Olahan, 2020

Dari hasil SPSS uji multikolinearitas, nilai Tolerance pada variabel TA, IHPS, dan TAxIHPS masing-masing sebesar 0.607, 0.992 , dan 0.603 , sehingga setiap nilai Tolerance berada di bawah angka 1 . Sedangkan nilai VIF pada variabel TA, IHPS, dan TAxIHPS masing-masing sebesar $1.648,1.008$, dan 1.658 , sehingga setiap nilai VIF tidak lebih besar dari 10. Oleh sebab itu dapat disimpulkan bahwa dalam model regresi tidak terjangkit multikolinearitas antar variabel independen dan variabel moderasinya, artinya tidak ada korelasi yang kuat antar ketiga variabel.

\section{Hasil Uji Autokorelasi}

Autokorelasi bertujuan untuk mengetahui ada tidaknya korelasi dalam variabel bebas yang mengganggu hubungan variabel bebas dengan variabel terikat (Ghozali, 2016). Model regresi yang baik adalah model regresi yang bebas autokorelasi. Untuk mengetahui adanya autokorelasi, dapat dilakukan dengan menguji uji Durbin Watson

Tabel 3

Hasil Uji Autokorelasi Durbin-Watson

Durbin-Watson $\quad 1,694$

Sumber: Data Olahan, 2020

Dari tabel hasil uji autokorelasi dapat diketahui bahwa nilai dW sebesar 1.694. Adapun nilai dL sebesar 1.82109 dan nilai dU sebesar 1.84225. Sesuai dengan kriteria uji Durbin Watson, jika $0<\mathrm{d}<\mathrm{dl}$ maka artinya tidak ada autokorelasi positif dan hasil penelitian ini menunjukkan bahwa $0<$ $1.694<1.82109$, sehingga pada model penelitian ini tidak ada autokorelasi positif.

\section{Hasil Uji Regresi Logistik}

Regresi logistik digunakan untuk mengetahui pengaruh variabel independen terhadap variabel dependen yang bersifat biner atau kualitatif yang memiliki dua kelas atau kategori (binary) (Ghozali,2016). Pada penelitian ini, model regresi logistik digunakan untuk melihat pengaruh variabel independen terhadap variabel dependen. Berikut merupakan hasil koefisien model regresi logistik pada penelitian ini. 
Tabel 4

Hasil Uji Regresi Logistik dari 0,05 . Hal ini menunjukkan bahwa $\mathrm{H}_{0}$ diterima dan $\mathrm{H}_{\mathrm{a}}$ ditolak, sehingga variabel kualitas laporan keuangan diperkuat oleh

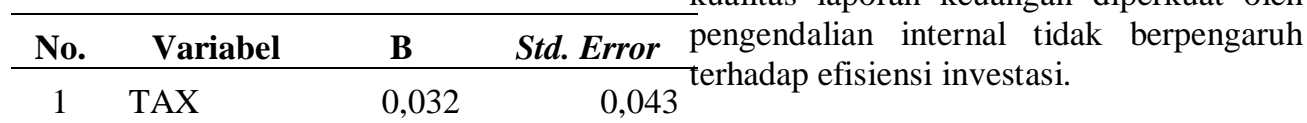

2 IHPS $\quad-1,730 \quad 0,688$ Pembahasan

3 TAXIHPS $0,014 \quad 0,025$ Berdasarkan hasil pengujian hipotesis 1a 4 LnTA $0,888 \quad 0,176$ dan $1 \mathrm{~b}$ menunjukkan bahwa kualitas 5 Age 0,001 laporan keuangan tidak berpengaruh 5 Age 0,001 0,005 terhadap over/under investment pada 6 Loss $\quad 0,817$ 0,380 BUMN baik listed dan non-listed periode $\begin{array}{rrr}\text { Constant } & -6,998 & 1,270 \\ \text { Sumber: Data Olahan, 2020 } & \text { yang menyatakan kualitas laporan keuangan }\end{array}$ Sumber: Data Olahan, 2020

Dari hasil uji Tabel 4, maka dapat disusun persamaan sebagai berikut:

$$
\begin{aligned}
\mathrm{Y}= & -6,998+0,032 \text { TA }-1,730 \text { IHPS + } \\
& 0,014 \text { TAXIHPS }+0,888 \text { LnTA + } \\
& 0,001 \text { Age }+0,817 \text { Loss }
\end{aligned}
$$

\section{Hasil Pengujian Hipotesis}

Tabel 5

\section{Hasil Pengujian Hipotesis}

\begin{tabular}{lcll}
\hline Variabel & Sig. & Keterangan & Keputusan \\
\hline TA & 0,458 & $\begin{array}{l}\text { Tidak } \\
\text { berpengaruh }\end{array}$ & Ditolak \\
IHPS & 0,012 & $\begin{array}{l}\text { Berpengaruh } \\
\text { positif } \\
\text { Tidak } \\
\text { berpengaruh }\end{array}$ & Diterima \\
TAXIHPS & 0,576 & Ditolak
\end{tabular}

Sumber: Data Olahan, 2020

Kualitas laporan keuangan memiliki nilai signifikansi sebesar 0,458 yang lebih besar dari 0,05 . Hal ini menunjukkan bahwa $\mathrm{H}_{0}$ diterima dan $\mathrm{H}_{\mathrm{a}}$ ditolak, sehingga variabel kualitas laporan keuangan tidak berpengaruh terhadap efisiensi investasi. Pengendalian internal memiliki tingkat signifikansi sebesar 0,012 yang lebih kecil dari 0,05. Hal ini menunjukkan bahwa $\mathrm{H}_{0}$ ditolak dan $\mathrm{H}_{\mathrm{a}}$ diterima, sehingga variabel pengendalian internal berpengaruh positif terhadap keputusan efisiensi investasi. Kualitas laporan keuangan diperkuat pengendalian internal memiliki tingkat signifikansi sebesar 0,576 yang lebih besar investment ditolak. Hal ini dapat dikatakan bahwa kualitas dari laporan keuangan tidak dapat mempengaruhi kondisi investasi perusahaan berupa over/under investment. Dalam penelitian ini, kualitas laporan keuangan yang baik tidak dapat meningkatkan fungsi monitoring bagi pemegang saham dalam mengawasi keputusan investasi yang dibuat oleh manajer. Adanya upaya yang dilakukan manajer untuk meningkatkan kualitas laporan keuangan dengan menyajikan informasi laporan keuangan tidak dapat memberikan pandangan kepada investor bahwa manajer telah memberikan informasi yang berkualitas sehingga beberapa investorpun tidak bereaksi dan ini menandakan tidak adanya pengaruh terhadap over/under investment (Sudana, 2011). Senada dengan hasil penelitian Dwiwana (2012) dan Butar (2015), hasil penelitian ini juga memberikan makna bahwa ada kemungkinan manajemen perusahaan hanya akan mengungkapkan suatu informasi tertentu jika ada manfaat yang diperolehnya. Hal ini dapat terjadi akibat asimetri informasi antara pihak prinsipal dan agen atau pihak pemegang saham dan pihak manajemen perusahaan. Menurut

Dwiwana

(2012), perusahaan yang belum sepenuhnya mengikuti standar akuntansi yang berlaku juga bisa menyebabkan kualitas laporan keuangan tidak berpengaruh terhadap over/ berpengaruh negatif terhadap over/under 
under investment. Hal ini berarti semakin besar asimetri informasi, maka semakin besar dorongan bagi manajer untuk berperilaku oportunis. Hal inilah yang mengakibatkan manajer hanya akan mengungkapkan suatu informasi tertentu jika ada manfaat yang diperolehnya. Sedangkan apabila tidak ada manfaat yang diperoleh maka manajer akan mengubah atau memalsukan informasi laporan keuangan tersebut. Hasil penelitian ini sejalan dengan apa yang telah ditemukan Sudana (2011), Dwiwana (2012) dan Butar (2015).

Berdasarkan hasil pengujian hipotesis $2 \mathrm{a}$ dan $2 \mathrm{~b}$ menunjukkan bahwa pengendalian internal berpengaruh positif terhadap over/under investment pada BUMN baik listed dan non-listed periode 2015-2018. Sehingga hipotesis 2a dan $2 b$ yang menyatakan pengendalian internal terdapat pengaruh positif terhadap over/ under investment diterima. Dasar pengujian hipotesis terkait peran pengendalian internal BUMN adalah karena BUMN berperan dalam mengelola aset milik negara dan mengelola risiko usaha dalam setiap pengambilan keputusan yang terjadi akibat perubahan lingkungan bisnis. Oleh karena itu, BUMN wajib merancang dan menerapkan pengendalian internal yang efektif dalam pengelolaan risiko terpadu sebagai bagian dari corporate governance perusahaan. Hal tersebut diatur dalam ketentuan peraturan perundang-undangan tentang BUMN (UU Nomor 19 Tahun 2003) yang pelaksanaannya diserahkan kepada Badan Pemeriksa Keuangan (BPK) RI sebagai auditor yang akan melakukan penilaian terhadap keefektifan pelaksanaan pengendalian internal dan kepatuhan pada ketentuan perundang-undangan.

Kualitas pengendalian internal dapat memiliki efek yang signifikan pada pengambilan keputusan pengguna informasi keuangan sehingga mempengaruhi keputusan investasi perusahaan. Selain itu, pengendalian internal dapat menurunkan kesenjangan informasi antara manajer dan pemegang saham. Perusahaan yang menerapkan pengendalian internal yang baik maka investasi yang dilakukan perusahaan menjadi optimal, kemungkinan terjadinya over investment dan under investment mengalami penurunan. Adanya kelemahan pengendalian internal menunjukkan adanya masalah informasi dalam sistem laporan keuangan perusahaan, sehingga diduga bahwa perusahaan dengan pengungkapan pengendalian internal yang lemah akan menunjukkan perilaku investasi yang tidak efisien. Hasil penelitian ini sejalan dengan penelitian Ashbaugh-Skaife, et al., (2008), Arens, et al., (2017) dan Chalmers, et al., (2018).

Berdasarkan hasil pengujian, hipotesis 3a dan $3 \mathrm{~b}$ menunjukkan bahwa kualitas laporan keuangan terhadap over/ under investment yang diperkuat oleh pengendalian internal tidak mampu mempengaruhi over/under investment pada perusahaan BUMN baik listed dan nonlisted periode 2015-2018. Sehingga hipotesis $3 \mathrm{a}$ dan $3 \mathrm{~b}$ yang menyatakan kualitas laporan keuangan terhadap over/ under investment yang diperkuat oleh pengendalian internal ditolak hal ini disebabkan karena kurangnya perhatian dari manajer perusahaan sehingga banyak terjadi kesalahan. Menurut Mulyadi (2016), pengendalian internal hanya dapat memberikan keyakinan memadai bagi manajemen dan dewan komisaris berkaitan dengan pencapaian tujuan pengendalian internal. Kemungkinan pencapaian tersebut dipengaruhi oleh keterbatasan bawahan yang melekat dalam pengendalian internal. Selain itu, pengendalian internal tidak dapat melengkapi atau mengurangi peran kualitas laporan keuangan dalam memberikan informasi mengenai proyek-proyek investasi yang dapat memberikan pengaruh over / under investment dan juga pengendalian internal tidak cukup menguatkan kualitas laporan keuangan (Harto dan Rahmawati, 2014).

Meskipun pengendalian internal yang ditetapkan sudah baik, tetapi belum 
terlaksana dan diterapkan secara efektif akan menyebabkan kualitas laporan keuangan yang dihasilkan kurang tepat. Jika kualitas laporan keuangan yang dihasilkan kurang tepat akan menimbulkan banyak ketidaksesuaian antara proses yang berjalan dengan peraturan yang berlaku. Hal ini dapat dibuktikan dari nilai rata-rata perusahaan yang sudah menerapkan pengendalian internal sebesar 2,302, sedangkan sisanya masih belum menerapkan pengendalian internal secara efektif sehingga kualitas laporan keuangan yang dihasilkan tidak semakin baik dan menyebabkan tidak adanya efisiensi investasi. Hasil penelitian ini sejalan dengan apa yang telah ditemukan oleh Yendrawati (2013), Akbar (2014), dan Fikri (2016).

\section{Simpulan dan Saran}

\section{Simpulan}

Penelitian ini bertujuan untuk menguji pengaruh kualitas laporan keuangan terhadap over/under investment serta kualitas laporan keuangan terhadap over/ under investment yang dimoderasi oleh pengendalian internal pada perusahaan BUMN periode 2015 sampai dengan 2018. Hasil pengujian hipotesis tidak mendukung agency theory yang menjelaskan laporan keuangan yang berkualitas akan memungkinkan pengawasan yang lebih baik sehingga manajer lebih bertanggung jawab dan dapat membantu manajer menghasilkan keputusan-keputusan investasi yang tepat. Namun hasil penelitian ini berbanding terbalik dengan pernyataan diatas dan memberikan bukti bahwa kualitas laporan keuangan tidak berpengaruh terhadap efisiensi investasi. Dari hasil penelitian ini dapat diambil kesimpulan sebagai berikut:

1. Kualitas laporan keuangan tidak berpengaruh signifikan terhadap over/ under investment.
2. Pengendalian internal berpengaruh positif terhadap terhadap over/under investment.

3. Kualitas laporan keuangan tidak memiliki pengaruh signifikan terhadap over/under investment meskipun telah dimoderasi dengan pengendalian internal.

Dalam penelitian ini, perusahaan dengan pengendalian internal yang baik merupakan poin penting untuk menjembatani asimetri informasi antara pihak manajemen perusahaan dan pemilik perusahaan meskipun kualitas laporan keuangan masih belum memiliki dampak signifikan terhadap over/under investment.

\section{Saran}

Keterbatasan dalam penelitian ini adalah adanya kesulitan dalam mengakses data lengkap dari website BUMN disertai dengan website masing-masing BUMN karena tidak semua data yang dibutuhkan selama periode penelitian tersedia. Selain itu, kurangnya periode pengamatan sehingga hasil penelitian belum dapat mencerminkan pelaksanaan pengendalian internal pada perusahaan BUMN secara keseluruhan. Berdasarkan simpulan dan keterbatasan penelitian, maka bagi penelitian selanjutnya disarankan untuk mempertimbangkan menggunakan sampel penelitian pada perusahaan BUMN dan menambah periode pengamatan sehingga hasil penelitian dapat mencerminkan pelaksanaan pengendalian internal secara keseluruhan.

\section{Daftar Pustaka}

Akbar, R.A. (2014). Faktor-Faktor Yang Mempengaruhi Kualitas Laporan Keuangan Pemerintah Daerah. Thesis. Jurusan Akuntansi Universitas Pendidikan Indonesia. Jakarta

Arens, A. A., R. J. Elder, dan M. S. Beasley. (2017). Auditing and 
Assurance Services: An Inte-grated Approach. Fourteenth Edition. Pearson.

Ashbaugh-Skaife, H., D. W. Collins, W. R. Kinney Jr, dan R. LaFond. (2008). The Effect of SOX Internal Control Deficiencies and Their Remediation on Accrual Quality. The Accounting Review.

Beatty, A., L. Scott, dan J. Weber. (2010). Financial Reporting Quality, Private Information, Monitoring, and the Lease-versus-Buy Decision. The Accounting Review.

Biddle, G. C., H. Gilles, dan S. V. Rodrigo. (2009). How Does Financial Reporting Quality Relate To Investment Efficiency? Journal of Accounting and Economics.

Butar-Butar, S. (2015). Dampak Kualitas laporan Keuangan, Regulasi Pengendalian Internal dan Keterbatasan Keuangan Terhadap Inefisiensi Investasi. Jurnal Akuntansi dan Keuangan.

Chalmers, K., D. Hay, dan H. Khlif. (2018). Internal Control in Accounting Research: A Review. Journal of Accounting Literature.

Chen, F., Hope, \& Li. (2011). Financial Reporting Quality and Investment Efficiency of Private Firms in Emerging Markets. The Accounting Review, Vol. 86, No. 4, hlm 12551288.

Chung, H. H., J. P. Wynn, dan H. Yi. (2013). Litigation Risk, Accounting Quality, and Investment Efficiency. Advances in Accounting Incorporating Advances in International Accounting.

Dwiwana, Benyamin. (2012). Pengaruh Kualitas Laporan Keuangan dan Tata Kelola terhadap Efisisiensi Investasi.. Skripsi : Fakultas Ekonomi Universitas Indonesia.

Fikri, M. A. \& Sri, R. R. (2016). Pengaruh Penerapan Standar Akuntansi Pemerintah, Kompetensi Aparatur dan Peran Audit Internal terhadap Kualitas Informasi Laporan Keuangan. Jurnal Ilmu Akuntansi.

Ghozali, I. (2016). Aplikasi Analisis Multivariant dengan Program IBM SPSS 23. Semarang: Badan Penerbit Universitas Diponogoro.

Gomariz, M. F. C. dan J. P. S. Ballesta. (2014). Financial Reporting Quality, Debt Maturity, and Investment Efficiency. Journal of Banking and Finance.

Harto, P. dan Rahmawati, A. (2014). Analisis Pengaruh Kualitas Pelaporan Keuangan terhadap Efisiensi Investasi. Diponegoro Journal of Accounting.

http://investasi.kontan.co.id/news/laporankeuangan-bermasalah-inirekomendasi-analis-untuk-investorgaruda-indonesia diakses tanggal 14 Oktober 2019.

Jaehong, L., C. Eunjung, dan C. Hyunjung. (2016). The Effect of Internal Control Weakness on Investment Efficiency. The Journal of Applied Business Research.

Jensen, M. C. \& W. Meckling. (1976). Theory of the firm: Managerial behavior, agency cost and ownership structure. Journal of Finance Economic.

Kothari, S.P., Leone, A.J., \& Wasley, C.E. (2005). Performance Matched Discretionary Accrual Measures. Journal of Accounting and Economics, 39 (1), 163-197.

Lambert, R. (2007). Contracting Theory and Accounting. Journal of Accounting and Economics.

Mulyadi, (2016). Sistem Akuntansi, Jakarta : Salemba Empat.

Mulyani, P., \& Suryawati, R. F. (2011). Analisis peran dan fungsi sistem pengendalian intern pemerintah (SPIP/PP NO.60 TAHUN 2008) dalam meminimalisasi tingkat salah saji pencatatan akuntansi keuangan pemerintah daerah. Jurnal 
Organisasi Dan Manajemen, 7(2), 102-106.

Peraturan Otoritas Jasa Keuangan Nomor: 75/POJK.04/2017 tentang Tanggung Jawab Direksi dan Laporan Keuangan.

Pradana. Utama, S dan Veronica, S. (2017). Kualitas Laporan Keuangan dan Pengendalian Internal, Terhadap Efisiensi Investasi. Journal Ekonomi dan Keuangan..

Sari, Luh Indah Novita. Suaryana, I. G. N. Agung. (2014). Pengaruh Kualitas Laporan Keuangan pada Efisiensi Investasi Perusahaan Pertambangan. E-Jurnal Akuntansi Universitas Udayana.

Sekaran, U. \& Bougie, R. (2017). Metode Penelitian untuk Bisnis. Jakarta: Salemba Empat.

Sudana, I Made. (2015). Manajemen Keuangan Perusahaan. Edisi Kedua. Jakarta: Erlangga

Susanto, Azhar. (2016). The effect of internal control on accounting information system. Medweel juornals International business management . ISSN: 1993-5250.

Yendrawati, R. (2013). Pengaruh sistem pengendalian intern dan kapasitas sumber daya manusia terhadap kualitas informasi laporan keuangan dengan faktor eksternal sebagai variabel moderating. Jurnal Akuntansi \& Auditing Indonesia. 